\title{
Tropical cyclone projections: changing climate threats for Pacific island defense installations
}

Article

Published Version

Widlansky, M. J., Annamalai, H., Gingerich, S. B., Storlazzi, C. D., Marra, J. J., Hodges, K. I., Choy, B. and Kitoh, A. (2019)

Tropical cyclone projections: changing climate threats for Pacific island defense installations. Weather, Climate, and Society, 11 (1). pp. 3-15. ISSN 1948-8327 doi: https://doi.org/10.1175/WCAS-D-17-0112.1 Available at https://centaur.reading.ac.uk/80182/

It is advisable to refer to the publisher's version if you intend to cite from the work. See Guidance on citing.

To link to this article DOI: http://dx.doi.org/10.1175/WCAS-D-17-0112.1

Publisher: American Meteorological Society

All outputs in CentAUR are protected by Intellectual Property Rights law, including copyright law. Copyright and IPR is retained by the creators or other copyright holders. Terms and conditions for use of this material are defined in the End User Agreement. 


\section{CentAUR}

Central Archive at the University of Reading

Reading's research outputs online 


\title{
Tropical Cyclone Projections: Changing Climate Threats for Pacific Island Defense Installations
}

\author{
Matthew J. Widlansky, ${ }^{\mathrm{a}}$ H. AnNAMAlai, ${ }^{\mathrm{b}}$ Stephen B. Gingerich, ${ }^{\mathrm{c}}$ Curt D. Storlazzi,${ }^{\mathrm{d}}$ \\ John J. MArra, ${ }^{\mathrm{e}}$ Kevin I. Hodges, ${ }^{\mathrm{f}}$ BARry ChOy, ${ }^{\mathrm{g}}$ AND AKIO $\mathrm{KiTOH}^{\mathrm{h}}$ \\ ${ }^{a}$ Joint Institute for Marine and Atmospheric Research, School of Ocean and Earth Science and Technology, \\ University of Hawai'i at Mānoa, Honolulu, Hawaii \\ ${ }^{\mathrm{b}}$ International Pacific Research Center, and Department of Oceanography, University of Hawai'i at Mānoa, Honolulu, Hawaii \\ ${ }^{\mathrm{c}}$ Oregon Water Science Center, U.S. Geological Survey, Portland, Oregon \\ ${ }^{\mathrm{d}}$ Pacific Coastal and Marine Science Center, U.S. Geological Survey, Santa Cruz, California \\ ${ }^{\mathrm{e}}$ NOAA/NESDIS/National Centers for Environmental Information, Inouye Regional Center, Honolulu, Hawaii \\ ${ }^{\mathrm{f}}$ Department of Meteorology, University of Reading, Reading, United Kingdom \\ ${ }^{\mathrm{g}}$ NOAA Commissioned Officer Corps/Liaison to U.S. Pacific Command, Honolulu, Hawaii \\ ${ }^{\mathrm{h}}$ Japan Meteorological Business Support Center, Tsukuba, Japan
}

(Manuscript received 26 October 2017, in final form 30 July 2018)

\begin{abstract}
Potential changing climate threats in the tropical and subtropical North Pacific Ocean were assessed, using coupled ocean-atmosphere and atmosphere-only general circulation models, to explore their response to projected increasing greenhouse gas emissions. Tropical cyclone occurrence, described by frequency and intensity, near islands housing major U.S. defense installations was the primary focus. Four island regions-Guam and Kwajalein Atoll in the tropical northwestern Pacific, Okinawa in the subtropical northwestern Pacific, and Oahu in the tropical north-central Pacific - were considered, as they provide unique climate and geographical characteristics that either enhance or reduce the tropical cyclone risk. Guam experiences the most frequent and severe tropical cyclones, which often originate as weak systems close to the equator near Kwajalein and sometimes track far enough north to affect Okinawa, whereas intense storms are the least frequent around Oahu. From assessments of models that simulate well the tropical Pacific climate, it was determined that, with a projected warming climate, the number of tropical cyclones is likely to decrease for Guam and Kwajalein but remain about the same near Okinawa and Oahu; however, the maximum intensity of the strongest storms may increase in most regions. The likelihood of fewer but stronger storms will necessitate new localized assessments of the risk and vulnerabilities to tropical cyclones in the North Pacific.
\end{abstract}

\section{Introduction}

\section{a. Tropical cyclones in the Pacific Islands}

The global number of tropical cyclones detected each year has remained remarkably constant $(82 \pm 8$ standard deviation) since reliable satellite meteorological measurements began in 1981, and likely for long before then. A total of $60 \%$ of global tropical cyclones form in the Pacific Ocean (Schreck et al. 2014), which is also where the strongest and largest storms on the planet occur. On average, 26 tropical cyclones form in the northwestern Pacific each year (Knapp et al. 2010; Schreck et al. 2014), with many threatening island communities. Tropical

Corresponding author: Matthew J. Widlansky, mwidlans@hawaii.edu cyclones frequently occur in the region between Guam and the Philippines referred to as "typhoon alley," where 7-8 tropical cyclones pass through during a typical year (Fig. 1). Here, the warm ocean provides energy and moisture to the atmosphere that supports powerful tropical cyclones (Fig. 2), which organize from atmospheric disturbances or clusters of convective storms (Chen et al. 2008). The resulting tropical cyclones spend almost their entire lifetime over the ocean, with warm moisture in the atmosphere fueling their potentially severe winds, hence the threat to the vast number of islands in the Pacific.

Pacific Islanders are well accustomed to the risks posed by severe tropical cyclones (Peduzzi et al. 2012), termed "hurricanes" in the eastern and central North Pacific, "typhoons" in the northwestern Pacific, and simply "cyclones" in the South Pacific. Here, we will refer to all 


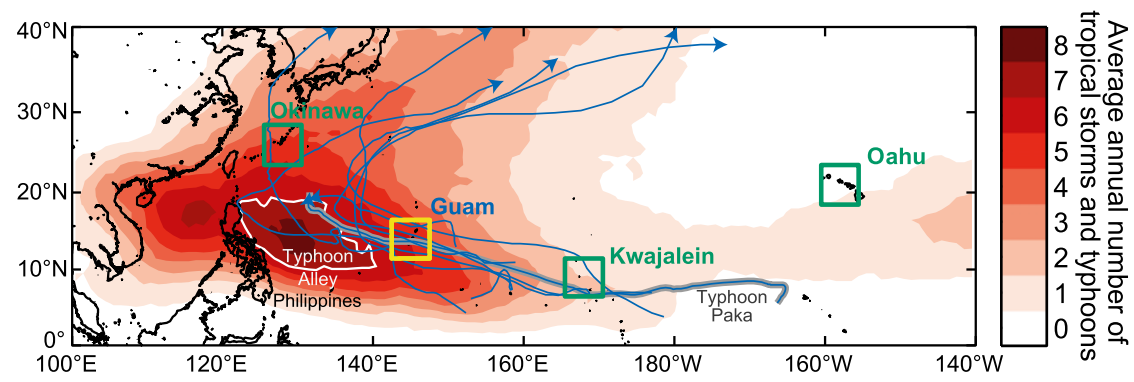

FIG. 1. Climatology (1979-2012) of observed tropical cyclones (red shading) and storm tracks (blue lines) passing near Guam (yellow box) during 1997. Several storms formed near Kwajalein, including Typhoon Paka (highlighted). Note the relative lack of storms near Oahu. Typhoon alley is outlined (white) where, during a typical year, more than six storms occur east of the Philippines. Tropical cyclone data are from the International Best Track Archive for Climate Stewardship (IBTrACS; Knapp et al. 2010), which we assess on a $1^{\circ} \times 1^{\circ}$ latitude-longitude grid.

tropical storms ${ }^{1}$ collectively as "tropical cyclones." The threat or realization of tropical cyclone damage has impacted military strategy in the Pacific Ocean for centuries, including during World War II (Williams 2015) when many storm-ravaged U.S. Navy ships sank, drowning hundreds of sailors. Whereas awareness of tropical cyclone risk is generally well developed among most vulnerable communities, including the military, the understanding of storm threats and likelihood has matured over a long period of relatively stable climate conditions. Such climate permanence is unlikely to continue this century with accelerating greenhouse warming (Christensen et al. 2013).

Guam, like other islands near typhoon alley, has previously been struck by many storms. In fact, the island's tropical cyclone risk is higher than that of any other part of the United States (Guard et al. 1999). Super Typhoon Karen was the strongest tropical cyclone to strike Guam in recorded history, passing over the island on 11 November 1962 with intensity equivalent to category 5. Sustained winds were estimated to be $175 \mathrm{mph}$ $\left(78 \mathrm{~m} \mathrm{~s}^{-1}\right)$, which destroyed the majority of infrastructure and vegetation (damage pictured in Fig. 3; Meyer 2014). The U.S. Department of Defense (DoD) assisted immediately following the disaster by evacuating hundreds of people and airlifting emergency supplies. Longerterm recovery was complicated by the passage of Typhoon Olive, which caused damage the following year. Guam has since been struck by many more typhoons, including Pamela (1976), Paka (1997), and Chataan (2002), yet the military and civilian population has consistently proved resilient.

\footnotetext{
${ }^{1}$ Tropical storms have sustained winds above $39 \mathrm{mph}\left(17 \mathrm{~m} \mathrm{~s}^{-1}\right)$. Hurricanes, typhoons, and cyclones have winds that exceed $74 \mathrm{mph}$ $\left(33 \mathrm{~m} \mathrm{~s}^{-1}\right)$.
}

To the east, near Hawaii, the ocean is somewhat cooler (i.e., less thermodynamic potential for intensifying storms) and winds near the surface as well as aloft are often less favorable for tropical cyclones to generate or maintain strength, although exceptions occur. Farther east, off the coast of Central America, conditions are much more suitable for tropical cyclone genesis and intensification, but most storms track well away from land and eventually dissipate over cooler water to the north and west.

Oahu - the most populous island in the Hawaiian Archipelago- - has experienced near-misses of strong tropical cyclones, but no direct strikes in over a century. The closest miss was Hurricane Iniki in 1992, which made its nearest approach to Oahu upon striking the neighboring island of Kauai. The Pacific Missile Range FacilityBarking Sands on Kauai is to the west of where Iniki made landfall, placing it in the weaker quadrant of the storm, and thus it sustained only minor damage (Reinhold 1992). Nevertheless, as reported by the New York Times during the recovery period, the military delayed missile tests previously scheduled as part of the Strategic Defense Initiative (the "Star Wars" program) and redirected efforts toward island-wide relief from the storm damage, which was substantial across the rest of Kauai. Clearly, it only takes a strike by one powerful tropical cyclone to cause major disruptions to society.

\section{b. Impacts of tropical cyclone strikes}

Tropical cyclones pose an intrinsic threat of destruction caused by intense winds, torrential rainfall, high waves, and/or storm surge to island-based infrastructure. Geographical constraints in the Pacific Ocean, such as vast distances between isolated islands and limited availability of developable land away from the coast, pose extrinsic threats. Climate and geographical threats are exacerbated 


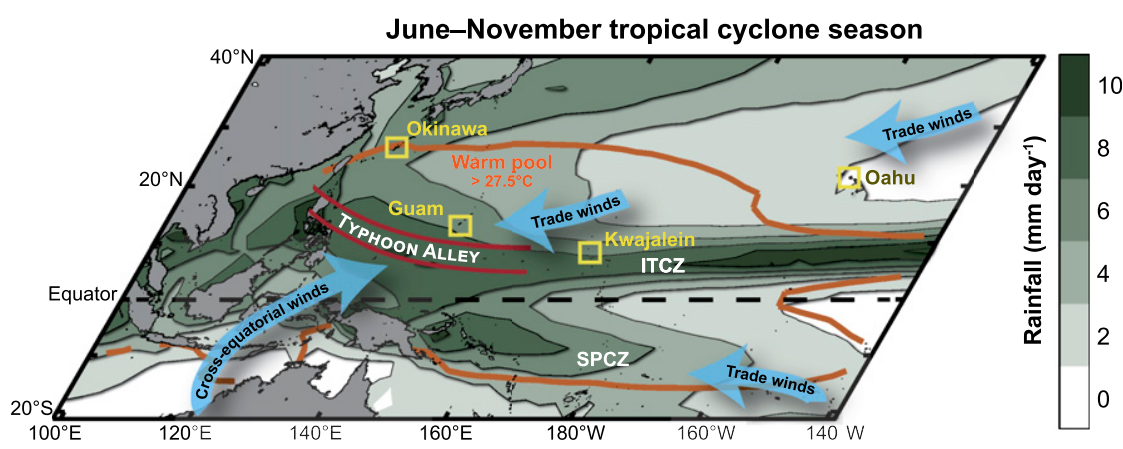

FIG. 2. Schematic of the climate conditions in the western and central Pacific during June-November when most tropical cyclones occur in the Northern Hemisphere. The warm pool of surface water temperatures greater than $27.5^{\circ} \mathrm{C}$ (enclosed by orange contour) provides energy and moisture to the atmosphere via evaporation and condensation that falls in organized heavy rainfall bands. Regions where trade winds converge (blue arrows), or slow, are often conducive for tropical cyclone genesis such as near the monsoon trough in the area called typhoon alley (Guam), the intertropical convergence zone (ITCZ; Kwajalein), and the South Pacific convergence zone (SPCZ; Southern Hemisphere islands during the opposite season). The combination of strong westerly winds above steady easterly trade winds will often result in the destructive shearing of a tropical cyclone passing near Hawaii.

by geopolitical pressures to maintain security forces in the North Pacific. The numerous DoD installations on islands throughout the tropical and subtropical North Pacific serve as bases to house personnel and equipment, secure harbors, protect landing strips, and facilitate missile launch and tracking capability for offensive and defensive strategies.

Furthermore, as part of its mission to provide humanitarian assistance and disaster relief (HADR), the DoD has a significant role in the North Pacific as a first responder for natural disasters, sometimes even while the military bases themselves recover from the effects of tropical cyclone strikes (e.g., damaging storms to Guam; Fig. 3). The HADR objective is to meet time-sensitive critical needs to reduce human suffering and, once that immediate need is fulfilled, other government or nongovernmental organizations assist in the longer-term recovery efforts. The military relief effort following Typhoon Haiyan, which struck the Philippines in 2013 as the strongest storm on record to make landfall, is an example of rapid recovery efforts including the opening of airports and conducting hundreds of airlift flights ${ }^{2}$ to deliver essential goods and evacuate disaster refugees (Parker et al. 2016). More recently, the military's humanitarian response to three major hurricanes striking Texas, Florida, Puerto Rico, and the U.S. Virgin Islands

\footnotetext{
${ }^{2}$ Aircraft based as far away as Joint Base Pearl Harbor-Hickam participated in the recovery effort during November-December 2013 (U.S. Pacific Command Operation DAMAYAN).
}

during 2017 necessitated a global rescheduling of military exercises (Starr 2017), which included redirecting resources away from conflict zones (e.g., Afghanistan) and other geopolitical hot spots (e.g., the Korean Peninsula).

DoD installations themselves routinely deal with limited access and coastal flooding, sometimes even without the impact of local severe weather occurring when high tides and large ocean swells generated far away combine to cause wave-driven setup and runup that results in coastal flooding (Becker et al. 2014; Cheriton et al. 2016; Storlazzi et al. 2018). Realizing the potential for combined threats such as a tropical cyclone striking a low-lying military installation or vulnerable civilian population far removed from the closest post-storm support, as well as likely changing rainfall patterns and sea level rise resulting from greenhouse warming, necessitates an assessment of the collective risk on a regional basis.

\section{c. Requirements for tropical cyclone occurrence}

Regardless of where tropical cyclones are initiated, the most threatening storms are those that track near vulnerable coastlines, an occurrence frequent in the northwestern Pacific but rare around Hawaii. Four essential ingredients are required for an initial disturbance, which is basically a conglomerate of several convective storms (i.e., mesoscale rain storms), to develop into a tropical cyclone (Gray 1979): 1) sufficient thermodynamic energy provided by a warm ocean surface layer, 2) abundant moisture in the atmosphere (i.e., high humidity), 3) circulation in the winds (i.e., cyclonic vorticity), 


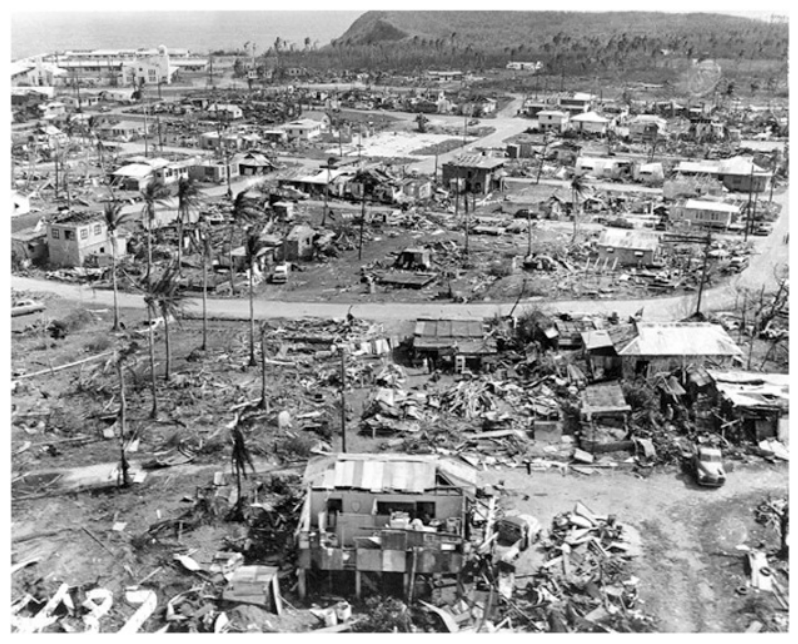

FIG. 3. Photograph of devastation from Super Typhoon Karen (1962), which destroyed 95\% of Guam's homes as well as caused severe damage to Andersen Air Force Base and Naval Base Guam. [Image courtesy of the 36th Wing History Office via http://www. andersen.af.mil/Portals/43/36\%20WSA \%20TENANT/ComRel/ Andersen \%20Heritage \%20Pamphlet.pdf.]

and 4) minimal vertical wind shear around developing storms. These requirements are met in most of the world's tropical and subtropical oceans between $5^{\circ}$ and $35^{\circ}$ latitude where there is enough background circulation caused by Earth's rotation and also abundant oceanic heat, but the ingredients are particularly plentiful in the northwestern Pacific (e.g., in typhoon alley; Figs. 1 and 2). Less conducive conditions for tropical cyclone genesis are found around Hawaii, where few storms originate but sometimes track by from the east or south where tropical cyclone conditions are more suitable.

Comparisons of how the four ingredients (heat, moisture, circulation, and consistent winds) varied with the long observational record of where storms originated (reliable since at least 1981) allowed for the calculation of a simple climate parameter called the genesis potential index (GPI) that describes where tropical cyclones are likely to form (e.g., Camargo et al. 2007). The GPI is based on SST and atmospheric profiles of temperature, pressure, wind, and moisture. As expected, in the present climate, the GPI peaks near typhoon alley in the tropical northwestern Pacific.

In this paper, we will discuss climate variations as they relate to how future tropical cyclones are likely to change this century with increasing greenhouse warming (section 2). We will present three methods of assessing future tropical cyclone occurrence based on state-of-the-art general circulation models (section 3). Results will be presented by island region in section 4 . Finally, we will discuss potential implications of changes in the tropical cyclone activity to the military and to civilians in the highlighted Pacific islands (section 5).

\section{Climate variability}

\section{a. Observed variability}

The Pacific Ocean's climate is dominated by variations in temperature, rainfall, winds, and severe weather (especially tropical cyclones) at the seasonal time scale and beyond. Other than the seasonal cycle, when the Northern Hemisphere tropical cyclone season begins in May or June and ends in November or December (the season is longer in the northwestern Pacific where storms can occur during any month because the sea surface stays warmer and wind shear stays weaker for longer), the dominant mode of variability is interannual in scale and is largely controlled by El Niño-Southern Oscillation (ENSO). For example, in 1997 Super Typhoon Paka formed farther east than is typical (Fig. 1), strengthened as it passed over the warm waters around Kwajalein in the Marshall Islands (which experienced moderate damage from coastal wave-driven flooding), and eventually reached peak intensity near Guam to the northwest. Andersen Air Force Base on Guam recorded arguably the world's highest measured wind speed exceeding $230 \mathrm{mph}\left(103 \mathrm{~m} \mathrm{~s}^{-1}\right)$ (Houston et al. 1998), but without question wind damage was widespread. In total, eight tropical cyclones tracked near Guam during 1997 as storm tracks shifted eastward from typhoon alley because more storms generated farther east where ocean surface waters were warmer than average in association with the developing strong El Niño. In addition to more typhoons occurring during El Niño, the storms typically generate farther east and have longer tracks over warm water, which allows more time for intensification. Several other notable tropical cyclones formed during 1997 from an El Niño-induced monsoon trough located more east than normal, including Typhoon Tina and Super Typhoon Winnie (Dillon and Andrews 1998), which both temporarily reduced military operations in Okinawa.

During the development of strong El Niño conditions in 2015 (Annamalai et al. 2015), typhoon activity was above normal around Guam (five storms threatened the region), just as it was during the lead up to the $1997 \mathrm{El}$ Niño event, and the central Pacific hurricane season (Avila 2016) was the most active on record although no storms struck the Hawaiian Islands. In early to mid-2016, as El Niño peaked and then ended, tropical cyclones were slow to form in the northwestern Pacific (five months of inactivity) although the typhoon season ended with a near-normal number of storms. Interestingly, the years following previous strong El Niño events (1983 and 1998) also had late starts in typhoon activity. 
Natural variability is well understood to be a part of the Pacific Ocean's climate both by scientists and island populations. Colloquial phrases such as "hurricanes form in summer and fall" and "no two typhoon/hurricane seasons are alike" epitomize a general understanding of the seasonal cycle and year-to-year variability, respectively. However, the forecasting of this variability in advanceand its communication to vulnerable populations ("how many strong storms should be expected?")—remains a work in progress (i.e., seasonal climate prediction).

\section{b. Long-term climate change}

Whereas resource and emergency operations managers for military and civilian assets, as well as the general public, seem well aware of natural fluctuations in the number and intensity of tropical cyclones, ${ }^{3}$ seemingly less attention outside the climate science community has been given to whether storm characteristics will change this century. It is well established that the threat of damaging storms varies with location in the short term (days to seasons), but there are wide-ranging perceptions-even among scientists ${ }^{4}$-about how tropical cyclones will be affected by increasing greenhouse gas concentrations as the oceans and atmosphere continue to warm.

Increases in computing have allowed the simulation of the coupled ocean-atmosphere climate system, providing a tool for diagnosing how tropical cyclone occurrence and intensity are likely to respond to greenhouse warming. These climate simulations have been incorporated into Intergovernmental Panel on Climate Change (IPCC) Assessment Reports via the experiments from phase 5 of the Coupled Model Intercomparison Project (CMIP5; Taylor et al. 2012). Using data from these simulations, we assess on a global, Pacific-wide, and island-region basis the projections of future change to tropical cyclone occurrence and intensity, which we define as the difference between the ends of the twenty-first and twentieth centuries.

\section{Methodology for assessing future tropical cyclones}

With respect to the well-known sensitivity of tropical cyclones to ENSO detected through observations

\footnotetext{
${ }^{3}$ The 2015 Hawaii Catastrophic Hurricane Plan/FEMA Region IX Hawaii Catastrophic Annex is one example of how tropical cyclone knowledge is communicated from the government to the public (http://dod.hawaii.gov/hiema/emergency-management/hawaiicatastrophic-hurricane-plan/).

${ }^{4}$ The WMO Statement on Tropical Cyclones and Climate Change (2006), although now outdated, assessed the state-of-knowledge at a time of peak scientific disagreement (https:/www.wmo.int/pages/ prog/arep/tmrp/documents/iwtc_statement.pdf).
}

(e.g., Camargo et al. 2007) and coupled climate models (e.g., Camargo 2013), we first selected a subsample of five CMIP5 models and one higher-resolution atmosphere-only general circulation model (Table 1) that capture the observed mean and interannual variability of key climate characteristics such as sea surface temperature (SST) and rainfall in the tropical and subtropical Pacific. We assessed the CMIP5 models (not shown) based on how well the simulated variables of each model matched observations of the mean climatology and annual cycle around islands near the monsoon trough (including Guam and Kwajalein), as well as interannual teleconnections inferred from linear regressions of tropical Pacific-wide fields onto SST anomalies in the Niño-3.4 region $\left(5^{\circ} \mathrm{N}-5^{\circ} \mathrm{S}, 170^{\circ}-120^{\circ} \mathrm{W}\right)$. All models were ranked by their temporal and spatial correlations, root-mean-square errors, and Taylor skill scores (Taylor 2001); from the rankings, five well-performing models were selected. A much higher-resolution version of one model was also included (Table 1) to assess how atmospheric grid size affects the results.

Biases in tropical cyclone genesis locations and storm tracks are present in CMIP5, even in the well-performing models that we selected. Of particular relevance to this study is the fact that too many tropical cyclones generate in the central North Pacific near Hawaii and not enough storms track west as far as Guam and Okinawa [compared to International Best Track Archive for Climate Stewardship (IBTrACS) observations]. To address such spatially dependent biases, we present climate change projections either as the difference between future minus historical simulations (Table 2; Figs. 4, 6, and 7) or by scaling the occurrence of tropical cyclones around island regions so that the mean of the historical period matches that of observations (Fig. 5). Furthermore, for all future change analyses, we maximized the signal-to-noise ratio by considering a high future greenhouse gas concentration scenario (RCP8.5) and also calculating the multimodel mean (except for Fig. 7, which shows only one higher-resolution model).

To estimate how tropical cyclones will respond to increasing greenhouse gases, one of three techniques is typically employed, each of which utilizes general circulation models to simulate future climate changes (Emanuel 2013). Applying the three approaches-which either rely solely on the coarse global models (e.g., CMIP5) themselves to 1) calculate climate indices favorable for storm formation (e.g., Camargo 2013) and 2) count model-generated storms (e.g., Strachan et al. 2013), or 3) to repeat the cyclone counting using a model downscaled to higher spatial resolution (e.g., Emanuel 2013)-yields both agreements and 
TABLE 1. Climate models used in this study. Historical and RCP8.5 experiments are averaged over 30-yr periods (1976-2005 and 20712100, respectively) except for MRI-AGCM3.2 (25-yr periods: 1979-2003 and 2075-99). (Expansions of acronyms are available online at http://www.ametsoc.org/PubsAcronymList.)

\begin{tabular}{|c|c|c|c|}
\hline Name & Type & $\begin{array}{l}\text { Horizontal resolution } \\
\text { (atmosphere) }\end{array}$ & Experiments \\
\hline CCSM4 & Coupled ocean-atmosphere & $0.9^{\circ} \times 1.3^{\circ}$ & $\begin{array}{l}\text { Historical } \\
\text { RCP8.5 }\end{array}$ \\
\hline CNRM-CM5 & Coupled ocean-atmosphere & $1.4^{\circ} \times 1.4^{\circ}$ & $\begin{array}{l}\text { Historical } \\
\text { RCP8.5 }\end{array}$ \\
\hline GFDL CM3 & Coupled ocean-atmosphere & $2.0^{\circ} \times 2.5^{\circ}$ & $\begin{array}{l}\text { Historical } \\
\text { RCP8.5 }\end{array}$ \\
\hline MIROC5 & Coupled ocean-atmosphere & $1.4^{\circ} \times 1.4^{\circ}$ & $\begin{array}{l}\text { Historical } \\
\text { RCP8.5 }\end{array}$ \\
\hline MRI-CGM3 & Coupled ocean-atmosphere & $1.1^{\circ} \times 1.1^{\circ}$ & $\begin{array}{l}\text { Historical } \\
\text { RCP8.5 }\end{array}$ \\
\hline MRI-AGCM3.2 & Atmosphere only & $20 \mathrm{~km}$ & $\begin{array}{l}\text { Historical (prescribed SST } \\
\text { from observations) } \\
\text { RCP8.5 (prescribed SST from } \\
\text { RCP8.5 coupled experiment) }\end{array}$ \\
\hline
\end{tabular}

disagreements on the expected future number of tropical cyclones.

\section{a. Large-scale atmospheric conditions}

Climate simulations are often assessed first for the necessary ingredients to support tropical cyclone genesis (i.e., GPI). Particularly important criteria are substantial energy for convection, moisture in the midtroposphere, and low vertical wind shear, which in the present climate are abundant in the tropical northwestern Pacific (i.e., typhoon alley near Guam; Figs. 1 and 2) but less so around the Hawaiian Islands. In assessments of historical and future simulations, we found that the GPI decreases (Fig. 4) in most of the tropical Pacific (especially south of Guam and around Kwajalein), which is consistent with projected drying in the midtroposphere global tropics (e.g., Knutson et al. 2010), but increases somewhat around Hawaii. Another notable exception to tropical cyclone formation becoming less favorable is in the subtropics, including near and eastward of Okinawa, where GPI increases with greenhouse warming also. The limitation of this approach is that such a genesis index does not account for changes in the necessary precursor disturbances or, once a storm has formed, in tropical cyclone tracks and intensity.

\section{b. Tracking tropical cyclones}

By objectively tracking tropical cyclones (Strachan et al. 2013) that are directly simulated by the models, we found a substantial decrease in annual storm counts from the historical to future both globally (120 vs 98) and in the Pacific Ocean ( 91 vs $75 ; 100^{\circ} \mathrm{E}-60^{\circ} \mathrm{W}$, which includes all of the Pacific Ocean as well as the southeastern Indian Ocean, Gulf of Mexico, Caribbean Sea,

TABLE 2. Regional tropical cyclone occurrence for each model and experiment. The ranges of storm counts expected during approximately $68 \%$ of years are in parentheses ( \pm 1 standard deviation from the mean). Boldface font indicates fewer future storms during active years (upper limit of the range decreases) and majority agreement among the multimodel ensemble. Simulations are not scaled to remove model biases in storm genesis and tracks, hence the different multimodel ranges compared to Fig. 5.

\begin{tabular}{|c|c|c|c|c|c|c|c|c|}
\hline \multirow[b]{2}{*}{ Model } & \multicolumn{2}{|c|}{ Guam } & \multicolumn{2}{|c|}{ Kwajalein } & \multicolumn{2}{|c|}{ Okinawa } & \multicolumn{2}{|c|}{ Oahu } \\
\hline & Historical & RCP8.5 & Historical & RCP8.5 & Historical & RCP8.5 & Historical & RCP8.5 \\
\hline CCSM4 & 1 to 4 & 1 to 4 & 0 to 4 & 0 to 4 & 1 to 4 & 1 to 4 & 0 to 2 & 0 to 2 \\
\hline CNRM-CM5 & 1 to 4 & 1 to 4 & 1 to 4 & 1 to 3 & 2 to 4 & 1 to 3 & 0 to 1 & 0 to 1 \\
\hline GFDL-CM3 & 3 to 6 & 1 to 4 & 3 to 7 & 0 to 3 & 1 to 3 & 1 to 4 & 2 to 4 & 1 to 3 \\
\hline MIROC5 & 1 to 7 & 0 to 3 & 1 to 7 & 0 to 4 & 0 to 3 & 0 to 2 & 0 to 2 & 0 to 2 \\
\hline MRI-CGM3 & 6 to 11 & 6 to 9 & 7 to 12 & 5 to 9 & 4 to 8 & 4 to 7 & 1 to 3 & 2 to 4 \\
\hline MRI-AGCM3.2 & 4 to 8 & 1 to 5 & 2 to 6 & 0 to 4 & 4 to 6 & 2 to 5 & 1 to 4 & 1 to 3 \\
\hline Multimodel mean & 3 to 7 & $\begin{array}{c}2 \text { to } 5 \\
\text { (4/6 models) }\end{array}$ & 2 to 7 & $\begin{array}{c}1 \text { to } 5 \\
\text { (5/6 models) }\end{array}$ & 2 to 5 & $\begin{array}{c}2 \text { to } 4 \\
\text { (4/6 models) }\end{array}$ & 1 to 3 & $\begin{array}{l}1 \text { to } 3 \\
\text { ( } 4 / 6 \text { models } \\
\text { increased or } \\
\text { unchanged) }\end{array}$ \\
\hline
\end{tabular}




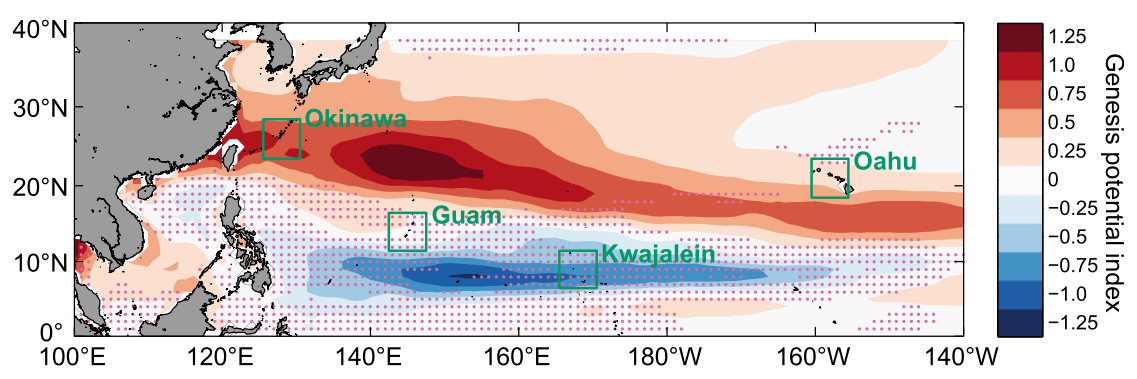

FIG. 4. Projected change in simulated tropical cyclone genesis potential (2071-2100 minus 1976-2005) calculated from historical and future (RCP8.5) climate simulations. The multimodel average from five well-performing climate models is shown. Stippling indicates where less than four out of five models agree on the sign of future change. The climate is projected to be less conducive for storms forming (blue shading) near Kwajalein but more storms may form (red shading) in the subtropics including near Okinawa and Oahu by the end of this century. Future change near Guam is more uncertain.

and northwestern Atlantic Ocean). Good intermodel agreement (4 out of 5 models) of such a decrease was found; however, inherent model biases (too many storms in the Pacific Ocean on average) and coarse spatial resolutions (ranging from $\sim 100$ - to $\sim 200-\mathrm{km}$ grid spacing; see Table 1), which limit formation of intense cyclones, pose uncertainties especially when counting smaller or weaker storms (Hodges et al. 2017). To assess the sensitivity to model horizontal resolution, we repeated the tracking analysis with a global higherresolution atmospheric model (20 km; MRI-AGCM3.2) forced by observed SST, which lessens current-climate biases, or forced by warming calculated from the CMIP5 projections added to the observations (Mizuta et al. 2012). The higher-resolution model also simulated fewer tropical cyclones in the future (61 vs 84 in the Pacific Ocean and neighbor basins $\left.; 100^{\circ} \mathrm{E}-60^{\circ} \mathrm{W}\right)$. Our results are consistent with a recent study using a regional atmospheric model with similar resolution and prescribed warming that projected a decrease in storms in the northwestern Pacific, which was not fully offset by slightly more storms forming in the northcentral Pacific (Zhang and Wang 2017). A somewhat different result-more future storms in the deep tropics of the northwestern Pacific and fewer in the subtropics-was obtained by Manganello et al. (2014) using a 16-km global atmospheric model, although there was small overall change in tropical cyclone occurrence.

\section{c. Dynamical downscaling}

There is an alternative approach to projecting future tropical cyclone occurrence that, instead of assessing coarse-resolution coupled ocean-atmosphere simulations or independent atmosphere-only projections, employs dynamical downscaling with a high-resolution model tuned to simulate observed storm counts (Emanuel 2013). The goal is to reduce uncertainty associated with tropical cyclone genesis biases. Using such an approach, where a prescribed number of initial disturbances are "seeded" in historical and future climate conditions, tropical cyclone genesis increases in most regions (especially in the northwestern Pacific; Kossin et al. 2016); however, it remains uncertain how sensitive dynamical downscaling results are to the seeding procedure. Furthermore, observed ENSO-related changes in the intensity distribution are not well resolved by the tropical cyclone seeding methodology (Emanuel et al. 2008). Questions remain such as "Does varying the number of initial disturbances alter the future change?" and "Will the future frequency of storm precursors be different?" Opposite results from the global simulations (coarse- and higher-resolution models), which do not employ any downscaling, do not support more tropical cyclones overall in the future.

\section{Results by island region}

\section{a. Fewer tropical cyclones}

Applying the tropical cyclone tracking method globally and then assessing the results regionally, we found that storm occurrence will decrease or remain the same by the end of the century compared to the historical period for most islands in the tropical and subtropical Pacific. Specifically, to diagnose storm activity around Guam, Kwajalein, Okinawa, and Oahu, we counted the number of observed and simulated tropical cyclones that tracked within $5^{\circ}$ latitude/longitude $(\sim 500 \mathrm{~km})$ regions centered on the respective islands (Fig. 5). For example, in the historical climate, 2-8 storms were likely to pass near Guam during any year, whereas up to 5 storms passed near Kwajalein and no more than 2 storms passed near Oahu. In the future climate, we found that tropical cyclone occurrence is likely to decrease near Guam (1 to 6 storms) and Kwajalein (no more than 2 storms), which 
a)
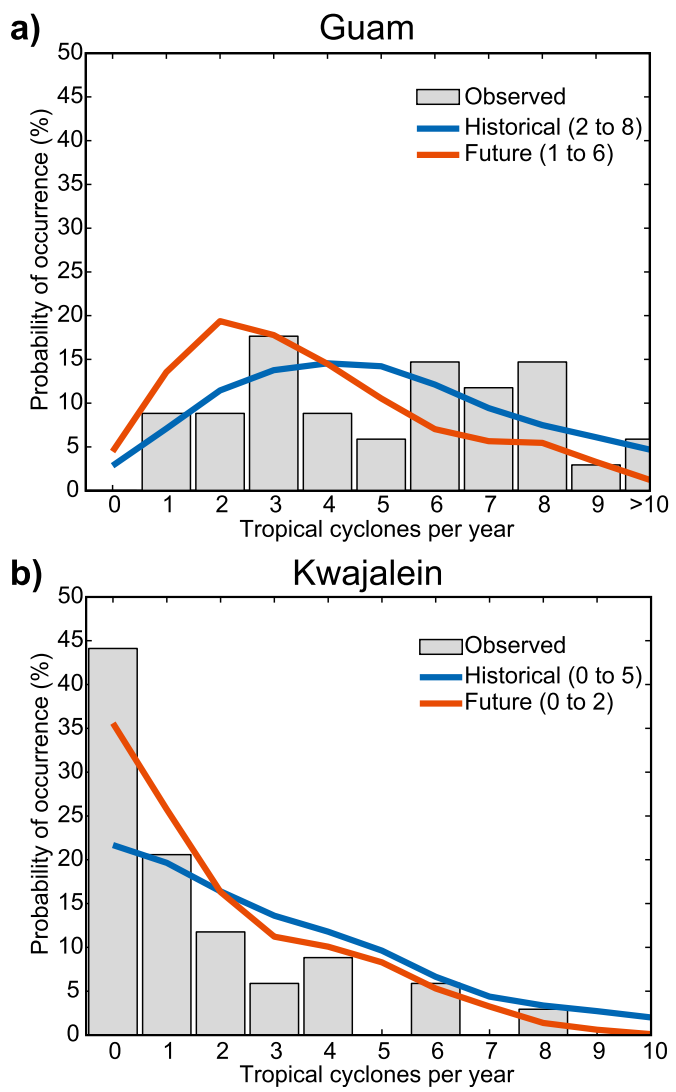

c)

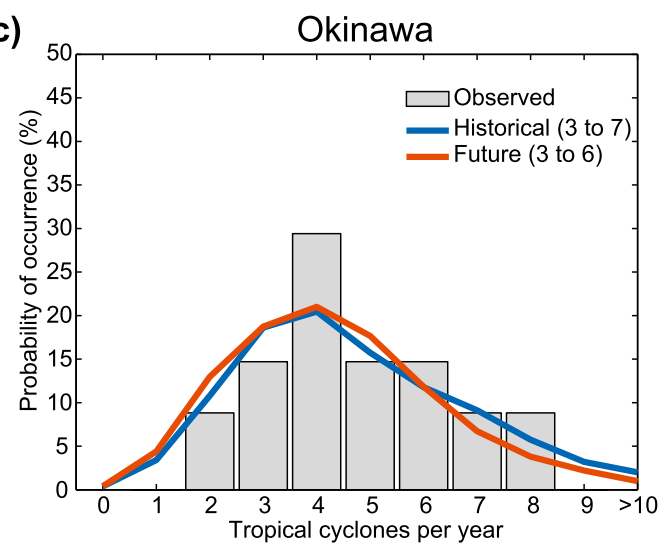

d)

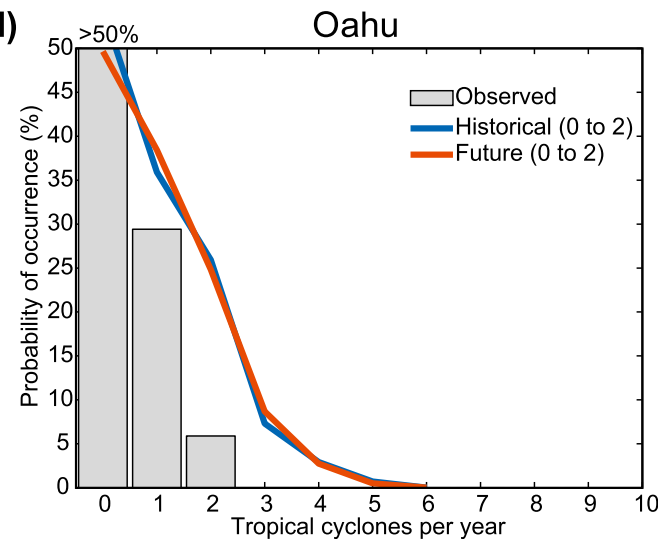

FIG. 5. Probability of tropical cyclone occurrence for observations (1979-2012; gray), simulations of the historical period (1976-2005; blue), and the future (RCP8.5; orange) climate with greenhouse warming (2071-2100) around (a) Guam, (b) Kwajalein, (c) Okinawa, and (d) Oahu. Shown is the multimodel average of simulations from five CMIP5 models and one higher-resolution atmospheric model. The ranges of storm counts expected during approximately $68 \%$ of years are in parentheses ( \pm 1 standard deviation from the mean). Simulations are scaled to remove model biases in storm genesis and tracks.

is consistent with the large-scale climate conditions becoming less conducive for storms generating near typhoon alley (Fig. 4). Almost no change in tropical cyclone occurrence was projected around Oahu and Okinawa (slightly less probability of years with 7 or more storms). For each of the regions, the majority of models that we analyzed agree on the sign of future changes (Table 2).

We found that future climate conditions are likely to support more storms forming near the Hawaiian Archipelago (i.e., higher GPI; Fig. 4), but this increase is offset by less storms originating in the northeastern Pacific, which sometimes track into the central Pacific. We caution, however, that other assessments of projected future tropical cyclone occurrence have sometimes found a robust increase around Hawaii associated with projected weaker vertical wind shear (e.g., Murakami et al. 2013), although storms would likely remain relatively rare.

Tropical cyclone frequency is strongly dominated by numerous weak storms, whereas damage statistics are usually controlled by rare, strong events (Pielke and Landsea 1998) that are generally not simulated by global models. Although there is some disagreement about how climate change might influence the overall frequency of tropical cyclones, especially around Hawaii, there is better agreement that the incidence of rare, high-intensity events (e.g., category 4 or 5 equivalent hurricanes/typhoons/cyclones) will increase in many places (Knutson et al. 2010; Sobel et al. 2016). Thus, the disparity in likely rates of future genesis might not be as serious an issue to policy makers, as there is emerging agreement on the incidence of high category storms.

\section{b. Stronger tropical cyclones}

The critical projection of future intensity change is an area of active research. Since it is apparent already that simulated tropical cyclone intensity depends strongly on the horizontal resolution of the atmospheric model and, furthermore, that models with finer-scale grids project a 


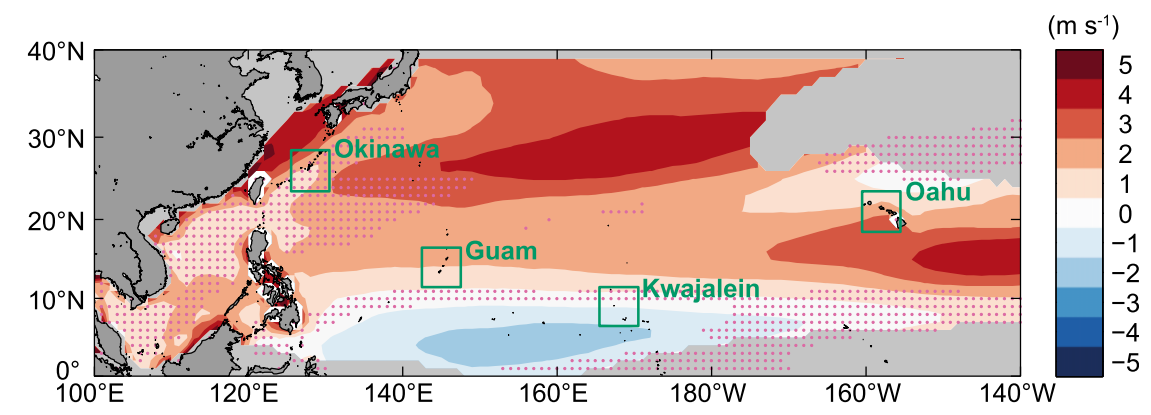

FIG. 6. Maximum potential intensity change (2071-2100 minus 1976-2005) calculated from historical and future (RCP8.5) simulations of SST and pressure, as well as atmospheric profiles of temperature and moisture. The multimodel average from five climate models is shown only for ocean regions with future tropical cyclones projected to occur. Stippling indicates where less than four out of five models agree on the sign of future change. Potential intensity is likely to remain unchanged around Kwajalein ( -1 to $1 \mathrm{~m} \mathrm{~s}^{-1} ; \pm 2 \mathrm{mph}$ ) but to increase around Guam $\left(1-2 \mathrm{~m} \mathrm{~s}^{-1} ; 2-5 \mathrm{mph}\right)$ and Oahu $\left(1-3 \mathrm{~m} \mathrm{~s}^{-1} ; 2-7 \mathrm{mph}\right)$ by the end of this century. Future change near Okinawa is more uncertain.

greater increase of the strongest storms in the future (Manganello et al. 2014), we provide only a brief assessment of how the large-scale future climate conditions are likely to affect intensity and then comparison to directly simulated intensity changes in the higherresolution model. Definitively answering the question "How strong and frequent will future storms be?" will require the next generation of climate models [e.g., CMIP6 High Resolution Model Intercomparison Project (HighResMIP); Eyring et al. 2016] with much higher spatial resolution than are currently used, which are necessary to resolve atmospheric structures critical to intensifying storms.

For the fewer future tropical cyclones likely to form, there is scientific consensus that the projected warmer seas are conducive for some storms to reach a greater intensity compared to the historical average (Emanuel 1999; Knutson et al. 2010; Sobel et al. 2016; Yu et al. 2010). We estimate the maximum potential intensity (MPI) of tropical cyclones (i.e., highest sustained wind speed) by assessing the thermodynamic structure (Bister and Emanuel 2002; Holland 1997) of the simulated atmosphere (Fig. 6). For the MPI analysis, we assumed no changes in vertical wind shear, which could offset intensity increases or decreases. Around Oahu, the MPI future change is approximately $2 \mathrm{~m} \mathrm{~s}^{-1}$ more than present. A smaller increase in maximum wind speed is projected around Guam $\left(\sim 1 \mathrm{~m} \mathrm{~s}^{-1}\right)$. No change in MPI is projected around Kwajalein and projections are inconsistent across models around Okinawa. In the offequatorial North Pacific-especially in the central region around the Hawaiian Islands-SSTs are likely to warm faster than the tropical average and, thus, there is likely to be more energy available to support stronger winds (as well as the potential for more storms to generate; Fig. 4), although we project that the total number of storms tracking nearby is unlikely to change (Fig. 5).

To assess how changing atmospheric conditions (e.g., wind shear) may affect future tropical cyclone intensities, we compared the maximum storm vorticities simulated in the higher-resolution model during historical and future climate conditions (Fig. 7). In general, the direct simulation diagnoses higher maximum intensity east of the date line (including around Hawaii) and reduced intensity in the northwestern Pacific equatorward of $10^{\circ} \mathrm{N}$ (Kwajalein), which agrees qualitatively with the empirical projection (Fig. 6). Elsewhere in the northwestern Pacific (Guam and Okinawa), maximum intensity changes in the direct simulation disagree with the empirical results (decrease vs increase, respectively), although there are undetermined uncertainties (e.g., sensitivity to resolution, convection parameters, or ocean-atmosphere feedbacks, the latter of which are neglected) associated with assessment based on one particular atmospheric model.

\section{c. Summary}

We found no significant increase in the interannual occurrence of tropical cyclones by the end of the twentyfirst century (Fig. 5). Hawaii was the only region where the year-to-year standard deviation of storm occurrence remained the same, whereas the range of likely number of storms decreased for Guam, Kwajalein, and Okinawa (Table 2). There remains a possibility of enhanced ENSO-related tropical cyclone interannual variability, however, because some climate change experiments suggest that the atmospheric environment during future El Niño events will be more conducive for storm genesis (Chand et al. 2017). Yet, for the models that we have 


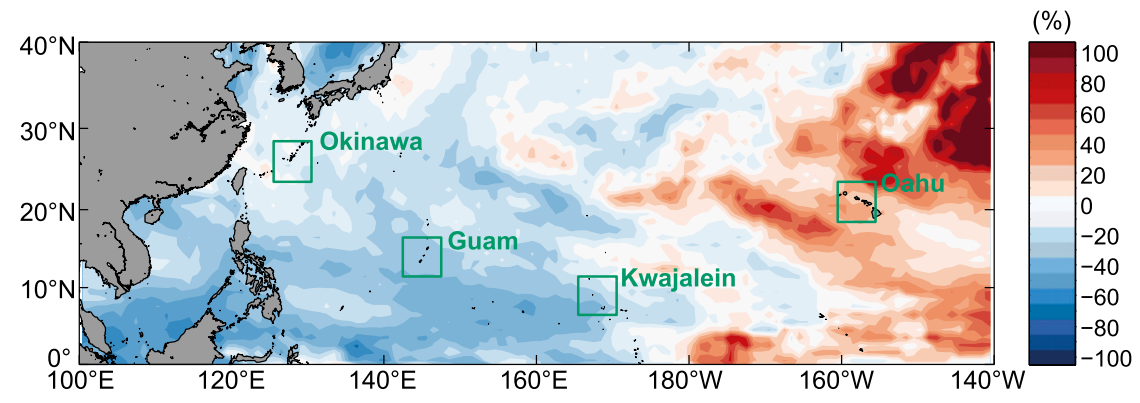

FIG. 7. Maximum simulated intensity change (2075-99 divided by 1979-2003, minus 1; expressed in \%) calculated from tropical cyclone low-level relative vorticity changes in one higherresolution atmospheric model (MRI-AGCM3.2) with prescribed SST from either the historical or future (RCP8.5) CMIP5 experiments. For each 25-yr period, the maximum 850-hPa relative vorticity occurring at each $1^{\circ} \times 1^{\circ}$ latitude-longitude grid point is identified using the tropical cyclone tracking method. The maximum relative vorticities simulated by MRI-AGCM3.2 decrease in the northwestern Pacific (Okinawa: $-10 \%$; Kwajalein: $-20 \%$; Guam: $-30 \%$ ) and increase in the northcentral Pacific (Oahu: $+30 \%)$ by the end of this century.

considered, any future increases in year-to-year variability seem to be overwhelmed by mean-state changes.

Averaging over future years, in contrast, we found pronounced long-term changes that are mostly consistent with other studies. The majority of the most realistic climate models from CMIP5 projected that overall tropical cyclone occurrence in the North Pacific will decrease with greenhouse warming (Table 2; Figs. 4 and 5) as less moisture rises to the layer of the atmosphere where convection is strongest. Decreased tropical cyclone numbers are likely a manifestation of the expected future weakening of the tropical circulation (Knutson et al. 2010). For different reasons-mainly that higher SSTs provide more thermodynamic energy to convert to wind (Emanuel 1999) - the same models project that the strongest tropical cyclones that do occur are likely to be even stronger (Fig. 6), especially in the northcentral Pacific where directly simulated maximum intensity increases (Fig. 7). CMIP6 will provide the opportunity to assess directly simulated tropical cyclones across an ensemble of higherresolution models, as well as to measure sensitivity of storm occurrence and intensity to climate features not considered here (e.g., the Madden-Julian oscillation), which are both necessary steps to better quantify uncertainty of future projections.

\section{Implications}

The projection of fewer but stronger tropical cyclones poses a number of policy implications for military and civilian planning (Tables 3 and 4 outline several strategies and resources), especially when considered together with other climate threats such as changing rainfall patterns and sea levels (e.g., Widlansky et al. 2015). The DoD already has a significant footprint in the North
Pacific, including multiple shore-side installations that are of critical strategic importance. In addition, the U.S. Pacific Command is headquartered on Oahu, making any increase in this island's vulnerability to impacts from tropical weather systems particularly concerning. Yet, climate threats-whether associated with gradual trends such as changing rainfall and sea level rise or extreme events such as tropical cyclones-are likely to continue or become more severe this century. Confidence in this projection stems from robustness across models shown to perform well at simulating the observed climate, along with consensus in the scientific understanding of processes driving climate variability, which will be further verified in CMIP6.

On the one hand, a lower frequency of tropical cyclone occurrence is likely to be a positive consequence of greenhouse warming; however, the projection of stronger storms may offset any decrease in overall cyclone energy from fewer storms. Because tropical cyclone damage potential increases logarithmically with wind speed, small increases in intensity of the strongest storms are likely to cause catastrophic consequences to affected islands (Guard and Lander 1999). For example, a $2 \mathrm{~m} \mathrm{~s}^{-1}(5 \mathrm{mph})$ increase of a category 4 tropical cyclone may result in approximately $75 \%$ more potential wind-related damage (Nordhaus 2006), which could prolong post-storm economic distress (Anttila-Hughes and Hsiang 2013).

Changes in the spatial distribution and severity of tropical cyclones could have significant impacts on DoD humanitarian missions and other operations. Increased frequency of the strongest storms, combined with other contributing factors like potential increases in population concentrations in vulnerable coastal regions, will make the North Pacific even more susceptible to significant 
TABLE 3. Strategies to prepare for changing tropical cyclone risks in the Pacific Islands.

\begin{tabular}{lc}
\hline \multicolumn{1}{c}{ Timeframe } & \multicolumn{1}{c}{ Preparation } \\
\hline Immediate actions & Increased public education at the individual and community level about tropical cyclone \\
warnings, as well as encouraging everyone to have a preparation and response plan. \\
Increased training for disaster responders, to improve their ability to respond to tropical \\
cyclones, as well as hazards like flooding, landslides, heat stress, drinking water shortages, \\
and infectious disease pandemics that may follow the storms. \\
Hardening critical DoD infrastructure in the most vulnerable regions. Relocating from near- \\
coastal and low-lying environments might be considered. \\
Examining cooperative capability for major commands on Oahu and/or distributing \\
headquarter physical locations to outer Hawaiian Islands or elsewhere may alleviate the \\
severity of impact to Pacific Command's ability to remain most effective in the event of \\
a major hurricane strike on Oahu. \\
Increase environmental satellite capability to support weather prediction and tropical storm \\
classification for the warfighter and civilian populations. \\
Research into tropical cyclones and their impacts under a changing climate, but also social \\
science research on topics such as risk perception and communication that address the critical \\
"human dimensions" of disaster-risk reduction. \\
\hline
\end{tabular}

impacts from these natural disasters. This would likely translate into larger-scale DoD responses to future requests for recovery assistance, both in geographic scope and duration. There are also potential strategic implications to more impactful storms. For example, a badly timed storm overlaid on a precarious geopolitical situation could be the tipping point for leadership change, unforeseen mass migration, or conflict with other nations.

We conducted the tropical cyclone assessment in the context of numerous ongoing military enhancements on islands in the North Pacific, many of which are vulnerable to climate hazards. The DoD plans to relocate about 5000 Marines and 1200 dependents to Guam, and will be constructing infrastructure to support this effort at a cost of about $\$ 200$ million (U.S. Navy 2015). The U.S. Air Force is building a nearly $\$ 1$ billion radar installation ("Space Fence") on Kwajalein, an atoll susceptible to wave-driven flooding (Cheriton et al. 2016; Storlazzi et al. 2018) that could wreak havoc on delicate equipment. Those planning future upgrades to islandbased defense infrastructures in the North Pacific would be wise to consider projected tropical cyclone changes collectively, as otherwise there is risk of being allayed by a false sense of security with respect to operational capabilities fostered by projections of likely less frequent but potentially stronger storms.

TABLE 4. Educational resources to assist military and civilian policymakers, planners, and island residents in keeping informed about both short and long-term tropical cyclone threats.

\begin{tabular}{lc}
\hline \multicolumn{1}{c}{ Objective } & Resource \\
\hline $\begin{array}{l}\text { Obtain the latest watches, warnings, } \\
\text { analyses, and forecasts out to five days } \\
\text { of hazardous tropical weather. }\end{array}$ & Central Pacific Hurricane Center (Hawaii region) (http://www.prh.noaa.gov/cphc/) \\
$\begin{array}{l}\text { Obtain probabilistic forecasts out to two } \\
\text { weeks and seasonal outlooks of the }\end{array}$ & and Okinawa regions) (http://www.metoc.navy.mil/jtwc/jtwc.html) \\
tropical cyclone threat. & Global Tropics Hazards and Benefits Outlook (http://www.cpc.ncep.noaa.gov/ \\
& products/precip/CWlink/ghazards/) \\
& Central Pacific Hurricane Center (Hawaii region) (http://www.prh.noaa.gov/cphc/) \\
& Tropical Storm Risk (northwestern Pacific including Guam, Kwajalein, and Okinawa \\
regions) (http://www.tropicalstormrisk.com/)
\end{tabular}


Acknowledgments. We acknowledge the World Climate Research Programme's Working Group on Coupled Modelling, which is responsible for CMIP, and we thank the climate modeling groups (listed in Table 1 of this paper) for producing and making available their model output. This work was primarily supported by the DoD Strategic Environmental Research and Development Program (SERDP) under projects RC-2334 and RC-2340. Partial support was provided by the NOAA Modeling, Analysis, Predictions, and Projections (MAPP) program via Awards NA17OAR4310110 (M.J.W.) and NA15OAR4310092 (H.A.), as well as the U.S. Geological Survey's Water Mission Area (S.B.G.) and Hazards Mission Area (C.D.S.). The authors thank three anonymous reviewers for constructive criticisms that improved the manuscript.

\section{REFERENCES}

Annamalai, H., V. Keener, M. J. Widlansky, and J. Hafner, 2015: El Niño strengthens in the Pacific: Preparing for the impacts of drought. AsiaPacific Issues, No. 122, East-West Center, Honolulu, HI, 1-10, https://www.eastwestcenter.org/publications/ el-niño-strengthens-in-the-pacific-preparing-the-impacts-drought.

Anttila-Hughes, J. K., and S. Hsiang, 2013: Destruction, disinvestment, and death: Economic and human losses following environmental disaster. 86 pp., https://doi.org/10.2139/ssrn.2220501.

Avila, L. A.: 2016 Eastern North Pacific hurricane season. National Hurricane Center, 12 pp., http://www.nhc.noaa.gov/data/tcr/ summary_epac_2015.pdf.

Becker, J. M., M. A. Merrifield, and M. Ford, 2014: Water level effects on breaking wave setup for Pacific Island fringing reefs. J. Geophys. Res., 119, 914-932, https://doi.org/10.1002/ 2013JC009373.

Bister, M., and K. A. Emanuel, 2002: Low frequency variability of tropical cyclone potential intensity 1 . Interannual to interdecadal variability. J. Geophys. Res., 107, 4801, https://doi.org/ 10.1029/2001JD000776.

Camargo, S. J., 2013: Global and regional aspects of tropical cyclone activity in the CMIP5 models. J. Climate, 26, 9880-9902, https://doi.org/10.1175/JCLI-D-12-00549.1.

_ K. A. Emanuel, and A. H. Sobel, 2007: Use of a genesis potential index to diagnose ENSO effects on tropical cyclone genesis. J. Climate, 20, 4819-4834, https://doi.org/10.1175/ JCLI4282.1.

Chand, S. S., K. J. Tory, H. Ye, and K. J. E. Walsh, 2017: Projected increase in El Niño-driven tropical cyclone frequency in the Pacific. Nat. Climate Change, 7, 123-127, https://doi.org/10.1038/ nclimate3181.

Chen, T.-C., S.-Y. Wang, M.-C. Yen, and A. J. Clark, 2008: Are tropical cyclones less effectively formed by easterly waves in the western North Pacific than in the North Atlantic? Mon. Wea. Rev., 136, 4527-4540, https://doi.org/10.1175/2008MWR2149.1.

Cheriton, O. M., C. D. Storlazzi, and K. J. Rosenberger, 2016: Observations of wave transformation over a fringing coral reef and the importance of low-frequency waves and offshore water levels to runup, overwash, and coastal flooding. J. Geophys. Res. Oceans, 121, 3121-3140, https://doi.org/10.1002/2015JC011231.

Christensen, J. H., and Coauthors, 2013: Climate phenomena and their relevance for future regional climate change. Climate
Change 2013: The Physical Science Basis, T. F. Stocker et al., Eds., Cambridge University Press, 1217-1308.

Dillon, C. P., and M. J. Andrews: 1998 Annual tropical cyclone report. Joint Typhoon Warning Center, 216 pp., www.metoc.navy.mil/ jtwc/products/atcr/1997atcr.pdf.

Emanuel, K. A., 1999: Thermodynamic control of hurricane intensity. Nature, 401, 665-669, https://doi.org/10.1038/44326. , 2013: Downscaling CMIP5 climate models shows increased tropical cyclone activity over the 21st century. Proc. Natl. Acad. Sci. USA, 110, 12 219-12 224, https://doi.org/10.1073/pnas.1301293110. , R. Sundararajan, and J. Williams, 2008: Hurricanes and global warming: Results from downscaling IPCC AR4 simulations. Bull. Amer. Meteor. Soc., 89, 347-367, https://doi.org/ 10.1175/BAMS-89-3-347.

Eyring, V., S. Bony, G. A. Meehl, C. A. Senior, B. Stevens, R. J. Stouffer, and K. E. Taylor, 2016: Overview of the Coupled Model Intercomparison Project phase 6 (CMIP6) experimental design and organization. Geosci. Model Dev., 9, 19371958, https://doi.org/10.5194/gmd-9-1937-2016.

Gray, W. M., 1979: Hurricanes: Their formation, structure and likely role in the tropical circulation. Meteorology over the Tropical Oceans, D. B. Shaw, Ed., Royal Meteorological Society, 155-218.

Guard, C., and M. A. Lander, 1999: A scale relating tropical cyclone wind speed to potential damage for the tropical Pacific Ocean region: A user's manual. WERI Tech. Rep. 86, Water and Environmental Research Institute of the Western Pacific, University of Guam, $58 \mathrm{pp}$.

_ M. P. Hamnett, C. J. Neumann, M. A. Lander, and G. H. Siegrist Jr., 1999: Typhoon vulnerability study for Guam. WERI Tech. Rep. 85, Water and Environmental Research Institute of the Western Pacific, University of Guam, http://www.weriguam.org/ reports/item/typhoon-vulnerability-study-for-guam.html.

Hodges, K., A. Cobb, and P. L. Vidale, 2017: How well are tropical cyclones represented in reanalysis datasets? J. Climate, $\mathbf{3 0}$, 5243-5264, https://doi.org/10.1175/JCLI-D-16-0557.1.

Holland, G. J., 1997: The maximum potential intensity of tropical cyclones. J. Atmos. Sci., 54, 2519-2541, https://doi.org/10.1175/ 1520-0469(1997)054<2519:TMPIOT>2.0.CO;2.

Houston, S., G. Forbes, and A. Chiu: 1998: Super Typhoon Paka's (1997) surface winds over Guam. Hurricane Research Division, Atlantic Oceanographic and Meteorological Laboratory, NOAA, accessed 1 June 2017, http://www.aoml.noaa. gov/hrd/project98/sh_proj1.html.

Knapp, K. R., M. C. Kruk, D. H. Levinson, H. J. Diamond, and C. J. Neumann, 2010: The International Best Track Archive for Climate Stewardship (IBTrACS): Unifying tropical cyclone best track data. Bull. Amer. Meteor. Soc., 91, 363-376, https:// doi.org/10.1175/2009BAMS2755.1.

Knutson, T. R., and Coauthors, 2010: Tropical cyclones and climate change. Nat. Geosci., 3,157-163, https://doi.org/10.1038/ngeo779.

Kossin, J. P., K. A. Emanuel, and S. J. Camargo, 2016: Past and projected changes in western North Pacific tropical cyclone exposure. J. Climate, 29, 5725-5739, https://doi.org/10.1175/ JCLI-D-16-0076.1.

Manganello, J. V., and Coauthors, 2014: Future changes in the western North Pacific tropical cyclone activity projected by a multidecadal simulation with a 16-km global atmospheric GCM. J. Climate, 27, 7622-7646, https://doi.org/10.1175/JCLI-D-13-00678.1.

Meyer, J., 2014: 36th Wing, Andersen AFB, Guam: 2014-2016 Heritage Pamphlet. 36th Wing Public Affairs Office, 32 pp.

Mizuta, R., and Coauthors, 2012: Climate simulations using MRIAGCM3.2 with 20-km grid. J. Meteor. Soc. Japan, 90A, 233258, https://doi.org/10.2151/jmsj.2012-A12. 
Murakami, H., B. Wang, T. Li, and A. Kitoh, 2013: Projected increase in tropical cyclones near Hawaii. Nat. Climate Change, 3, 749-754, https://doi.org/10.1038/nclimate1890.

Nordhaus, W. D., 2006: The economics of hurricanes in the United States. NBER Working Paper 12813, National Bureau of Economic Research, 47 pp.

Parker, T., S. P. Carroll, G. Sanders, J. E. King, and I. Chiu, 2016: The U.S. Pacific Command response to Super Typhoon Haiyan. Joint Force Quart., 82, 54-61, http://ndupress.ndu.edu/ JFQ/Joint-Force-Quarterly-82/Article/793262/the-us-pacificcommand-response-to-super-typhoon-haiyan/.

Peduzzi, P., B. Chatenoux, H. Dao, A. De Bono, C. Herold, J. Kossin, F. Mouton, and O. Nordbeck, 2012: Global trends in tropical cyclone risk. Nat. Climate Change, 2, 289-294, https:// doi.org/10.1038/nclimate1410.

Pielke, R. A., Jr., and C. W. Landsea, 1998: Normalized hurricane damages in the United States, 1925-1995. Wea. Forecasting, 13, 621-631, https://doi.org/10.1175/1520-0434(1998)013<0621: NHDITU $>2.0 . \mathrm{CO} ; 2$.

Reinhold, R., 1992: Storm left hard future for Hawaii's lush island. New York Times, 6 October 1992, https://www.nytimes.com/ 1992/10/06/us/storm-left-hard-future-for-hawaii-s-lush-island.html.

Schreck, C. J., K. R. Knapp, and J. P. Kossin, 2014: The impact of best track discrepancies on global tropical cyclone climatologies using IBTrACS. Mon. Wea. Rev., 142, 3881-3899, https:// doi.org/10.1175/MWR-D-14-00021.1.

Sobel, A. H., S. J. Camargo, T. M. Hall, C.-Y. Lee, M. K. Tippett, and A. A. Wing, 2016: Human influence on tropical cyclone intensity. Science, 353, 242-246, https://doi.org/10.1126/science.aaf6574.

Starr, B., 2017: Hurricane deployments stretch US military thin. CNN, 5 October 2017, https:/www.cnn.com/2017/10/04/politics/ hurricane-maria-us-military-mattis/index.html.
Storlazzi, C. D., and Coauthors, 2018: Most atolls will be uninhabitable by the mid-21st century because of sea-level rise exacerbating wave-driven flooding. Sci. $A d v$., 4, eaap9741, https://doi.org/10.1126/sciadv.aap9741.

Strachan, J., P. L. Vidale, K. Hodges, M. Roberts, and M.-E. Demory, 2013: Investigating global tropical cyclone activity with a hierarchy of AGCMs: The role of model resolution. J. Climate, 26, 133-152, https://doi.org/10.1175/JCLI-D-12-00012.1.

Taylor, K. E., 2001: Summarizing multiple aspects of model performance in a single diagram. J. Geophys. Res., 106, 71837192, https://doi.org/10.1029/2000JD900719.

— R. J. Stouffer, and G. A. Meehl, 2012: An overview of CMIP5 and the experiment design. Bull. Amer. Meteor. Soc., 93, 485498, https://doi.org/10.1175/BAMS-D-11-00094.1.

U.S. Navy, 2015: Supplemental Environmental Impact Statement, Guam and Commonwealth of the Northern Mariana Islands Military Relocation (2012 Roadmap Adjustments), 1625 pp., http://www.dtic.mil/dtic/tr/fulltext/u2/a623122.pdf.

Widlansky, M. J., A. Timmermann, and W. Cai, 2015: Future extreme sea level seesaws in the tropical Pacific. Sci. Adv., 1, e1500560, https://doi.org/10.1126/sciadv.1500560.

Williams, J., 2015: How typhoons at the end of World War II swamped U.S. ships and nearly saved Japan from defeat. Washington Post, 16 July 2015.

Yu, J., Y. Wang, and K. Hamilton, 2010: Response of tropical cyclone potential intensity to a global warming scenario in the IPCC AR4 CGCMs. J. Climate, 23, 1354-1373, https://doi.org/ 10.1175/2009JCLI2843.1.

Zhang, C., and Y. Wang, 2017: Projected future changes of tropical cyclone activity over the western North and South Pacific in a 20-km-mesh regional climate model. J. Climate, 30, 5923-5941, https://doi.org/10.1175/JCLI-D-16-0597.1. 